\title{
Evaluation of antimicrobial activity of a lectin isolated and purified from Indigofera heterantha
}

\author{
Sakeena Qadir, Ishfak Hussain Wani, Shaista Rafiq, Showkat Ahmad Ganie, Akbar Masood, \\ Rabia Hamid*
}

Department of Biochemistry, University of Kashmir, Srinagar, India

Email: ${ }^{*}$ rabeyams@yahoo.co.in

Received 13 August 2013; revised 26 September 2013; accepted 12 October 2013

Copyright (C) 2013 Sakeena Qadir et al. This is an open access article distributed under the Creative Commons Attribution License, which permits unrestricted use, distribution, and reproduction in any medium, provided the original work is properly cited.

\begin{abstract}
Indigofera heterantha commonly called indigo bush is a member of leguminoseae family found in the Himalayan region of Kashmir. A lectin has been isolated from the seeds of Indigofera heterantha by the purification procedure involving anion exchange chromatography on DEAE-cellulose followed by gel filtration chromatography on Sephadex G 100. Molecular characterization of the lectin was done by gel filtration and SDS-PAGE. Activity of the lectin was checked by hemagglutination assay and the sugar specificity by sugar inhibition tests. The antimicrobial activity of the purified lectin was carried out by Agar disc diffusion using appropriate standards. On the ion exchange column, the bound protein when eluted with 0 - 0.5 M NaCl gradient emerged as three peaks-peak I, peak II and peak III out of which only peak II showed the hemagglutinating activity. The lectin further resolved into two peaks G1 and G2 on gel filtration, with the lectin activity residing in G1, corresponding to a molecular weight of $70 \mathrm{KDa}$. The purified lectin named as Indigofera heterantha Lectin (IHL) produced a single band on SDS PAGE (18 $\mathrm{KDa})$, revealing the tetrameric nature of the lectin. It agglutinated human erythrocytes (A, B, AB, and $\mathrm{O}$ ). Hemagglutination was inhibited by D-galactose, Dmannose and $\mathrm{D}$-arabinose. The lectin is reasonably thermostable showing full activity within a temperature range of $30^{\circ} \mathrm{C}$ to $90^{\circ} \mathrm{C}$. $\mathrm{pH}$ stability of the lectin falls in the range of 2 - 9. IHL demonstrated a remarkable antibacterial activity against the pathogenic bacteria Klebsiella pneumoniae, Staphylococcus aureus, Escherichia coli, and Bacillus subtilis. IHL also inhibited the growth of phytopathogenic fungi Aspergillus niger, Aspergillus oryzae and Fusarium oxysporum.
\end{abstract}

\footnotetext{
"Corresponding author.
}

Keywords: Indigofera heterantha Lectin; Hemagglutination; Antimicrobial

\section{INTRODUCTION}

Lectins are proteins of non-immune origin that bind to carbohydrates and sugar containing substances in a specific and reversible way or precipitate glycoconjugates [1]. The main properties of lectins are based on their ability to interact with carbohydrates and thus combine with glycocomponents on the cell surface, leading to their biological properties [2]. Lectins are able to tightly bind to and cause the precipitation of specific polysaccharides and glycoproteins because they are polyvalent. They vary, however, in molecular size, amino acid composition, metal ion requirements, and three-dimensional structure [3]. Lectins can recognize mono-, oligo- or polysaccharides, as well as glycoconjugates and thus recognize glycoproteins or glycolipids, e.g. on the surface of cells [4]. Generally, lectins are glycoproteins consisting of subunits ranging in molecular mass from 25 to $35 \mathrm{kDa}$, arranged as dimers or tetramers, and existing as multiple isoforms sharing similar biochemical properties [5]. The subunits are usually identical or very similar, made up of single polypeptide chains that are encoded by different genes or by a family of closely related genes [6]. In addition to their carbohydrate binding activity, some of the lectins such as those of hemagglutinin, galactosidase, polynucleotide adenosine glucosidase, or ribosome inactivating proteins, also show other biological activities [7]. Lectins in higher plants defend against pathogenic bacteria and fungi by recognizing and immobilizing the infecting microorganisms via binding, thereby preventing their subsequent growth and multiplication. They act as a sort of immune system for plants by "sticking" themselves to the structural carbohydrates (sugars) of invaders. Recently, lectin biology has applied these tools in the biomedical field and also in the treat- 
ment of diseases, including cancer [8]. Another application reported in the literature involving lectins is their antimicrobial activity where lectins may act against microorganisms by interfering with their growth and playing a role in defense systems [9]. Antibacterial activity on Gram-positive and Gram-negative bacteria occurs through the interaction of lectin with components of the bacterial cell wall including techoic and teichuronic acids, peptidoglycans and lipopolysaccharides; study revealed that the isolectin I from Lathyrus ochrus seeds binds to muramic acid and muramyl dipeptide through hydrogen bonds between ring hydroxyl oxygen atoms of sugar and carbohydrate binding site of lectin and hydrophobic interactions with the side chains of residues Tyr100 and Trp128 of isolectin I [10]. The inhibition of fungal growth can occur through lectin binding to hyphas resulting in poor absorption of nutrients as well as by interference on spore germination process [11]. The polysaccharide chitin is constituent of fungi cell wall and chitin-binding lectins showing antifungal activity; impairment of synthesis and/or deposition of chitin in cell wall may be the reasons of antifungal action [12]. Probably the carbohydrate-binding property of lectin is involved in the antifungal mechanisms and lectins of different specificities can promote distinct effects. In this report, we describe the purification and characterization of a lectin from Indigofera heterantha seeds and also the evaluation of its potential antimicrobial activity.

\section{MATERIALS AND METHODS}

The plants (Indigofera heterantha) were collected from the premises of the Department of Botany of Kashmir University and were authenticated from Centre of Plant Taxonomy of the same department. DEAE-cellulose and Sephadex G-100 were purchased from Sigma Aldrich Company, USA. Other chemicals were of highest purity grade.

\subsection{Isolation and Purification of Lectins from Indigofera heterantha Seeds}

Twenty five grams of dry Indigofera heterantha seeds were allowed to swell in distilled water at $4^{\circ} \mathrm{C}$ overnight. The seeds were then ground in a mortar and pestle and proteins extracted by suspending the ground seed meal in $0.15 \mathrm{M} \mathrm{NaCl}(10 \% \mathrm{w} / \mathrm{v})$ for 1 hour at room temperature and subjecting the mixture to homogenization in a Remi auto mix blender for $10 \mathrm{~min}$. The homogenate thus produced was stirred for $2 \mathrm{~h}$ at $4^{\circ} \mathrm{C}$ and then filtered through double layered cheesecloth. The filtrate was centrifuged at $5000 \times \mathrm{g}$ for $20 \mathrm{~min}$ at $4^{\circ} \mathrm{C}$. The pellet was discarded. The storage proteins present in the supernatant were precipitated by slowly adding $1 \mathrm{M}$ acetic acid to the stirred solution until $\mathrm{pH} 5.0$ was reached. After an additional hour of stirring at $4^{\circ} \mathrm{C}$, the suspension was again centrifuged at $5000 \times \mathrm{g}$ for $20 \mathrm{~min}$. The pellet was again discarded and the supernatant readjusted to $\mathrm{pH} 8.0$ by the addition of $0.1 \mathrm{M} \mathrm{NaOH}$. The supernatant thus obtained was dialyzed against $20 \mathrm{mM}$ phosphate buffer, $\mathrm{pH} 7.2$ for $24 \mathrm{hr}$. The viscous extract thus obtained was the crude extract and was stored at $4^{\circ} \mathrm{C}$.

To purify the lectin further, the crude extract was subjected to ion exchange chromatography on DEAE cellulose column in $50 \mathrm{mM}$ Tris-HCL buffer, $\mathrm{pH}$ 8. The protein was eluted using linear sodium chloride gradient from 0 to $0.5 \mathrm{M}$. The active fractions were pooled and dialyzed against Tris-HCL buffer, $\mathrm{pH} 8$.

To check the size homogeneity, the active fractions eluted from ion-exchange column were chromatographed on Sephadex G 100 column in 0.05 M Tris-HCl, pH 8.0. The charge homogeneity of the fractions eluted from gel filtration column was checked by polyacrylamide gel electrophoresis. Estimation of the subunit molecular weight of the purified lectin was done by SDS-PAGE.

\subsubsection{Protein Estimation}

Protein concentration was determined by the method of Lowry et al. [13] using BSA as the standard protein.

\subsubsection{Polyacrylamide Gel Electrophoresis}

Polyacrylamide gel electrophoresis in presence and absence of SDS was performed at $\mathrm{pH} 8.3$ on $10 \%$ and $12 \%$ gels respectively with a discontinuous buffer system. The gels were stained with Coomassie Brilliant Blue R-250.

\subsection{Hemagglutination Assay and Inhibition of Hemagglutination}

The hemagglutination activity of the lectin was determined by a slight variation of the method devised by Peumans et al. [14], using human erythrocytes bearing blood groups A, B, O, AB and chick erythrocytes. The human blood was collected from SKIMS, Srinagar and chick blood was obtained from a local veterinary outlet. The erythrocytes were separated by centrifugation of the blood at $2500 \mathrm{~g}(5000 \mathrm{rpm})$ for $10 \mathrm{~min}$, and the R.B.Cs washed thrice with normal saline. Finally the erythrocytes were suspended in normal saline to obtain a final concentration of $3 \%$ erythrocyte suspension. The assay of agglutination was carried out on glass slides by mixing the erythrocytes with the test solution. $50 \mu 1$ erythrocyte suspensions (A, B, O, AB and Chick erythrocytes) were taken on a slide. To this, $50 \mu \mathrm{l}$ of the test solution was added. After an incubation period of $15 \mathrm{~min}$ at room temperature, agglutination was monitored unaided on the slides. Also the control slide, using the buffer instead of the lectin solution was run simultaneously. The lectin activity has been expressed as EU (Erythroagglutinating Unit). One erythroagglutinating unit (EU) is defined as 
the minimum amount of the lectin per $\mathrm{ml}$ required to give positive agglutination of $1 \mathrm{ml}$ of a $5 \%$ human erythrocyte suspension. EU is expressed as $\mu \mathrm{g}$ of lectin per $\mathrm{ml}$ of the protein solution.

The carbohydrate specificity was investigated by observing the inhibition of the lectin induced hemagglutination by various sugars namely $\mathrm{D}$-glucose, $\mathrm{D}$-galactose, D-mannose, fructose, lactose, maltose, sucrose, ribose and sugar derivatives like $\mathrm{N}$-acetyl galactosamine and $\mathrm{N}$-acetyl glucosamine. The inhibition assay was performed on glass slides. Different dilutions of the above sugars (final volume $20 \mu \mathrm{l}$ ) were added to glass slides on which agglutination was performed. To each dilution, 20 $\mu l$ of purified lectin was added. The mixture was incubated at room temperature for $1 \mathrm{hr}$ after which $80 \mu \mathrm{l}$ of $3 \%$ suspension of erythrocytes was added to each slide. The minimum concentrations of each sugar capable of fully inhibiting agglutination after $1 \mathrm{hr}$ at room temperature were noted.

\subsection{Effect of $\mathrm{pH}$ and Temperature on the Stability of the Lectin}

The $\mathrm{pH}$ dependence of the lectin was determined by incubating $50 \mu \mathrm{g}$ of IHL with buffers in different $\mathrm{pH}: 0.1$ $\mathrm{M}$ glycine/ $\mathrm{HCl}(\mathrm{pH} 2-3), 0.05$ sodium acetate/acetic acid ( $\mathrm{pH} 4-5), 0.05 \mathrm{M}$ potassium phosphate ( $\mathrm{pH} 6$ - 7), $0.05 \mathrm{M}$ Tris- $\mathrm{HCl}(\mathrm{pH} 8-9)$ and $0.1 \mathrm{M}$ glycine- $\mathrm{NaOH}$ (pH $10-11$ ) for $5 \mathrm{hrs}$ at $25^{\circ} \mathrm{C}$ and $\mathrm{pH}$ adjusted to 7.2 just prior to hemagglutination assay. The effect of temperature on the agglutinating activity of the IHL lectin was determined by carrying out assay at different temperatures according to the method described by Ngai and $\mathrm{Ng}$ [15]. The purified lectin was incubated in a water bath for $30 \mathrm{~min}$ at various temperatures: $10^{\circ} \mathrm{C}, 20^{\circ} \mathrm{C}, 30^{\circ} \mathrm{C}$, $40^{\circ} \mathrm{C}, 50^{\circ} \mathrm{C}, 60^{\circ} \mathrm{C}, 70^{\circ} \mathrm{C}, 80^{\circ} \mathrm{C}, 90^{\circ} \mathrm{C}$ and $100^{\circ} \mathrm{C}$, and then cooled to $20^{\circ} \mathrm{C}$ in each case. Hemagglutination assay was carried out as previously described. The assay was performed in duplicate [16].

\subsection{Molecular Weight Determination}

The subunit molecular mass of the lectin was estimated by discontinuous SDS-PAGE according to method of Laemmli [17]. Native molecular mass was determined by gel filtration on Sephadex G-100 column using the following protein markers: BSA (66 kDa), Ovalbumin (45 $\mathrm{kDa})$, Pepsin (34.7 kDA) and cytochrome c (12.4 kDa). The gel filtration data was treated according to the relation given by Andrew [18].

\subsection{Evaluation of Antimicrobial Activity}

For the evaluation of antibacterial activity of Indigofera heterantha lectin, firstly all the glassware was sterilized in an autoclave. After sterilization, the subsequent steps were the preparation of media, selection of the test organisms and sensitivity tests of antibacterial activity. Purified IHL was used for analysis. Ciprofloxacin 5 $\mu \mathrm{g} / \mathrm{ml}$ was used as standard. Human pathogenic bacteria Pseudomonas spp. Escherichia coli, Shigella bodyi, Klebsiella pneumonea, Streptococci, Salmonella typhi and Staphylococcus aureus obtained from Department of Microbiology, Sheri Kashmir Institute of Medical Sciences Srinagar were used to check the antibacterial activity. Antifungal activity was checked against Aspergillus niger, Aspergillus Oryzae and Fusarium oxysporum and were obtained from Sheri Kashmir University of Agricultural Science and Technology, Shalimar. The Agar disc diffusion method was used to determine the antimicrobial activity. This test was done according to the method of Edward [19] and Lansing [20]. The microbial (bacterial/fungal) colony was picked by the inoculating wire and the media plates were subsequently inoculated with specific microbial strains and labeled accordingly. The inoculated plates were left to dry for at least $5-10$ minutes, after which Whatman filter paper discs $6 \mathrm{~mm}$ (previously saturated with crude extract and purified lectin) were placed on the plates with the help of a sterilized forcep. Standard antibiotic discs of ciprofloxacin (positive control) were also impregnated on plates at previously labeled positions. Loaded plates were kept as such for some time under Laminar hood and then incubated at $37^{\circ} \mathrm{C}$ for 24 hours in case of bacterial strains and 48 hours in case of fungal strains in the incubator. A transparent ring around the paper disc signified antimicrobial activity. Zone diameters $(\mathrm{mm})$ around each of the discs were measured to the nearest $\mathrm{mm}$.

\section{RESULTS}

\subsection{Isolation and Purification}

A lectin was isolated and purified from the Indigofera heterantha seeds by ion exchange chromatography on DEAE-Cellulose followed by gel filtration on Sephadex G-100. The crude extract obtained after homogenization of the finely ground seed meal in $0.15 \mathrm{M} \mathrm{NaCl}$ was assayed for hemagglutinating activity using human erythrocytes of blood group types $\mathrm{A}, \mathrm{B}, \mathrm{AB}$ and $\mathrm{O}$. This was then applied on to a DEAE-Cellulose column equilibrated with $50 \mathrm{mM}$ Tris- $\mathrm{HCl}$ buffer, $\mathrm{pH} 8$ (containing $0.02 \% \mathrm{NaN}_{3}$ ). Major portion of the protein in crude extract passed unbound through the column. This fraction did not carry any hemagglutinating activity. The bound protein when eluted with $0-0.5 \mathrm{M} \mathrm{NaCl}$ gradient emerged as three peaks - peak I, peak II and peak III out of which only peak II showed the hemagglutinating activity. Typical profile is shown in Figure 1. Fractions under the active peak were pooled together and concentrated, and then subjected to gel filtration on Sephadex 


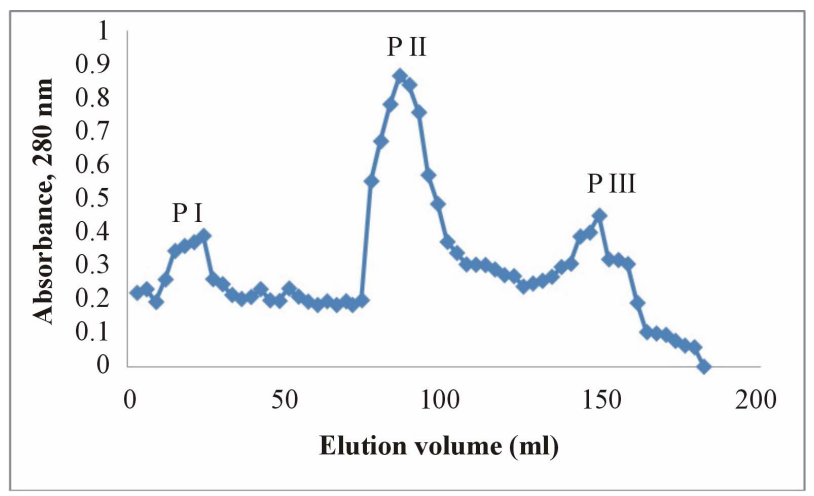

Figure 1. Ion exchange chromatography of the crude extract on DEAE-cellulose column $(1.6 \times 10 \mathrm{~cm})$. About $60 \mathrm{mg}$ of protein was applied on DEAE-cellulose column pre-equilibrated with $50 \mathrm{mM}$ Tris-HCL buffer, $\mathrm{pH}-8$. The protein was eluted using 0 - $0.5 \mathrm{M} \mathrm{NaCl}$ gradient in $5 \mathrm{ml}$ fractions at a flow rate of 30 $\mathrm{ml} / \mathrm{hr}$.

G-100 column $(2.6 \times 40 \mathrm{~cm})$ where it resolved into two peaks, G1 and G2 (Figure 2). Lectin activity resided majorly in G1. The fractions in the peak (G1) were again pooled together, concentrated and stored at $4^{\circ} \mathrm{C}$ in 0.05 $\mathrm{M}$ Tris- $\mathrm{HCl}$, $\mathrm{pH} 8.0$ containing $0.02 \% \mathrm{NaN}_{3}$. This preparation was called the Indigofera heterantha lectin or IHL, and was used for physicochemical and biological characterization. Data on the purification of Indigofera heterantha lectin is summarized in Table 1. The yield of the lectin was about $0.46 \%$ and about a 5.2 fold purification of the lectin was achieved.

\subsection{Electrophoretic Analysis}

The charge homogeneity of the lectin was established by subjecting the lectin to polyacrylamide gel electrophoresis under native conditions. The electrophoretogram shows that the lectin moved as a single band (Figure 3). In 12\% SDS-PAGE, the lectin again moved as a single band, establishing that the lectin is composed of similar type of subunits (Figure 4).

\subsection{Characterization}

\subsubsection{Molecular Weight Determination}

Molecular weight of the Indigofera heterantha lectin as determined by gel filtration on a Sephadex G-200 column $(2.6 \times 40 \mathrm{~cm})$ equilibrated in $0.05 \mathrm{M}$ Tris- $\mathrm{HCl}$ buffer, pH 8 was about $70 \mathrm{KDa}$ (Figure 2). In SDSPAGE under reducing conditions, the lectin moved as a single protein band with molecular weight corresponding to $18 \mathrm{KDa}$. The results of SDS-PAGE (Figure 4) together with gel filtration data revealed that IHL (Indigofera heterantha lectin) is a homotetramer.

\subsubsection{Hemagglutination}

The Indigofera heterantha lectin (IHL) does not show any marked blood group specificity (Table 2). As is evident, the lectin agglutinated human erythrocytes of all blood groups, being somewhat more specific towards blood group A erythrocytes. Extent of hemagglutination was found to be same, when human erythrocytes of blood group $\mathrm{A}, \mathrm{B}, \mathrm{AB}$ and $\mathrm{O}$ were incubated with purified IHL for overnight at $7^{\circ} \mathrm{C}$ and for $6 \mathrm{hr}$ at $27^{\circ} \mathrm{C} \&$ $37^{\circ} \mathrm{C}$.

\subsubsection{Carbohydrate Specificity}

In order to determine the sugar specificity of the lectin, inhibition and reversal of inhibition by a number of sugars and sugar derivatives was studied. In each case the ability of the sugar to inhibit agglutination was measured. Results on such specificity studies are shown in Table 3. It is clear from the table that arabinose is the most potent inhibitor of the Indigofera heterantha lectin mediated hemagglutination followed by the disaccharide sucrose. Galactose also inhibits agglutination though at very high concentrations.

\subsection{Effect of $\mathrm{pH}$ and Temperature}

The examination of IHL activity in different $\mathrm{pH}(\mathrm{pH} 2$ 13) values showed that the lectin was stable in the $\mathrm{pH}$ range of 2 - 9 (Figure 5) indicating that the amino acid residues involved in carbohydrate binding are not affected by changes in $\mathrm{pH}$ in this range. The activity however falls of rapidly thereafter, with essentially all activity lost after $\mathrm{pH} 12$. The purified lectin sample was found to be heat stable up to $90^{\circ} \mathrm{C}$, at incubation temperatures of 30 to $90^{\circ} \mathrm{C}$ (Figure 6). Even heating at $100^{\circ} \mathrm{C}$ for 30 minutes caused a loss of only $25 \%$ of its original activity. However the hemagglutinating activity of the lectin was completely lost when exposed to $110^{\circ} \mathrm{C}$.

\subsection{Antimicrobial Activity}

\subsubsection{Antibacterial Activity}

Purified lectin obtained from ion exchange chromatography and gel filtration chromatography as well as the crude extract were tested against different bacterial strains and compared to that of antibacterial antibiotic, ciprofloxacin. The results of the sensitivity test are shown in Figure 7. Purified IHL ( $500 \mu \mathrm{g} / \mathrm{ml})$ exhibited a significant antibacterial effect on four strains namely Klebsiella pnuemoniae, Staphylococcus aureus, Escherichia coli, and Bacillus subtilis. The diameters of the zones of inhibition by the addition of IHL were $10 \mathrm{~mm}, 6$ $\mathrm{mm}, 4 \mathrm{~mm}$ and $4 \mathrm{~mm}$ respectively. The diameters of the zones of inhibition with the standard drug used were 22 $\mathrm{mm}, 20 \mathrm{~mm}, 22 \mathrm{~mm}$ and $13 \mathrm{~mm}$ for the four strains respectively. Results with the crude extract were not significant. 
Table 1. Purification profile of Indigofera heterantha lectin.

\begin{tabular}{|c|c|c|c|c|c|c|c|c|}
\hline Purification step & $\begin{array}{l}\text { Volume } \\
(\mathrm{ml})\end{array}$ & $\begin{array}{l}\text { Protein } \\
(\mathrm{mg} / \mathrm{ml})\end{array}$ & $\begin{array}{l}\text { Total protein } \\
\quad(\mathrm{mg})\end{array}$ & $\begin{array}{l}\text { Activity } \\
\text { (EU) }\end{array}$ & $\begin{array}{c}\text { Total } \\
\text { activity }\end{array}$ & $\begin{array}{l}\text { Specific activity } \\
\left(\text { E. } U^{*} / \mathrm{mg}\right)\end{array}$ & $\begin{array}{c}\text { Fold } \\
\text { purification }\end{array}$ & $\begin{array}{l}\text { Yeild } \\
\%\end{array}$ \\
\hline Crude extract & 500 & 9 & 4500 & 81 & 40,500 & 9 & 1 & 100 \\
\hline $\begin{array}{l}\text { Ion exchange } \\
\text { Chromatography }\end{array}$ & 10 & 1.7 & 17 & 52.02 & 520.2 & 30.6 & 3.4 & 1.28 \\
\hline $\begin{array}{l}\text { Sephadex gel } \\
\text { chromatography }\end{array}$ & 4 & 1 & 4 & 46.80 & 187.2 & 46.8 & 5.2 & 0.46 \\
\hline
\end{tabular}

* One erythroagglutinating unit (EU) is defined as the minimum amount of the lectin per ml required to give positive agglutination of $1 \mathrm{ml}$ of a $5 \%$ erythrocyte suspension. EU is expressed in microgram of lectin/ $\mathrm{ml}$ of the protein solution.

Table 2. Blood group specificity of purified Indigofera heterantha lectin.

\begin{tabular}{cc}
\hline Blood group & Specific activity $\left(\mathrm{EU}^{*} / \mathrm{mg}\right)$ \\
\hline A & 46.8 \\
B & 35.3 \\
O & 31.2 \\
\hline
\end{tabular}

* One erythroagglutinating unit (EU) is defined as the minimum amount of the lectin per $\mathrm{ml}$ required to give positive agglutination of $1 \mathrm{ml}$ of a $5 \%$ erythrocyte suspension. EU is expressed in $\mu \mathrm{g}$ of lectin $/ \mathrm{ml}$ of the protein solution.

Table 3. Carbohydrate Inhibition of Indigofera heterantha lectin mediated hemagglutination.

\begin{tabular}{cc}
\hline Sugar & Minimal inhibitory concentration $(\mathrm{mM})^{*}$ \\
\hline Arabinose & 0.039 \\
Sucrose & 0.188 \\
D-galactose & 0.275 \\
Ribose & No inhibition \\
N-acetyl galactosamine & No inhibition \\
Raffinose & No inhibition \\
Lactose & No inhibition \\
Mannose & No inhibition \\
Glucose & No inhibition
\end{tabular}

*Minimum sugar concentration necessary for complete inhibition of agglutination of human erythrocytes by Indigofera heterantha lectin solution of 4 $\mu \mathrm{g} / \mathrm{ml}$.

\subsubsection{Antifungal Activity}

In vitro antifungal susceptibility by IHL was determined against three phytopathogenic fungi Aspergillus oryzie, Aspergillus niger and Fusarium oxysporum with ciprofloxacin as positive control. The lectin showed some, though not significant inhibition of growth against all the three strains with a zone inhibition diameter of $9 \mathrm{~mm}, 3$ $\mathrm{mm}$ and $6 \mathrm{~mm}$ respectively in each case (Table 4).

\section{DISCUSSION}

Legume lectins represent the largest and most thoroughly studied family of the simple lectins. The members of this

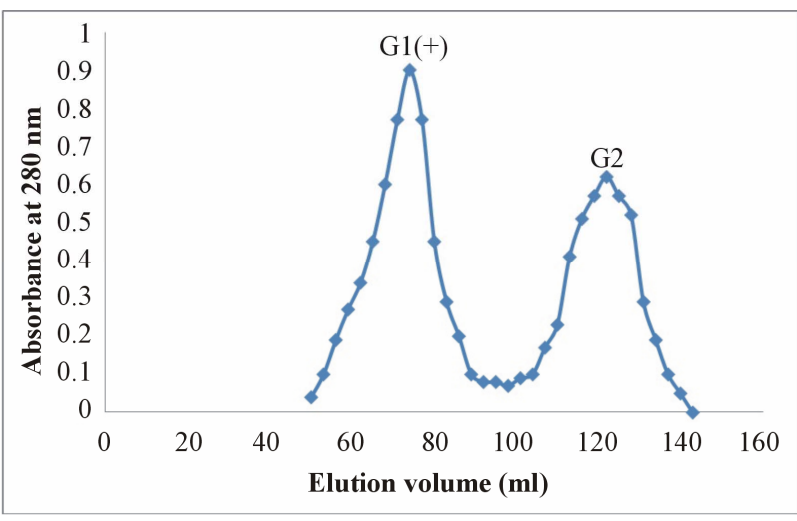

Figure 2. Gel filtration of fraction PII from ion exchange column on Sephadex G-100 column $(2.6 \mathrm{~cm} \times 40 \mathrm{~cm})$. About 20 milligram of protein was applied on the column pre-equilibrated with $50 \mathrm{mM}$ Tris-HCL buffer, $\mathrm{pH}$ 8.0. The protein was eluted using the same buffer in $3 \mathrm{ml}$ fractions at a flow rate of $30 \mathrm{ml} / \mathrm{hr}$.

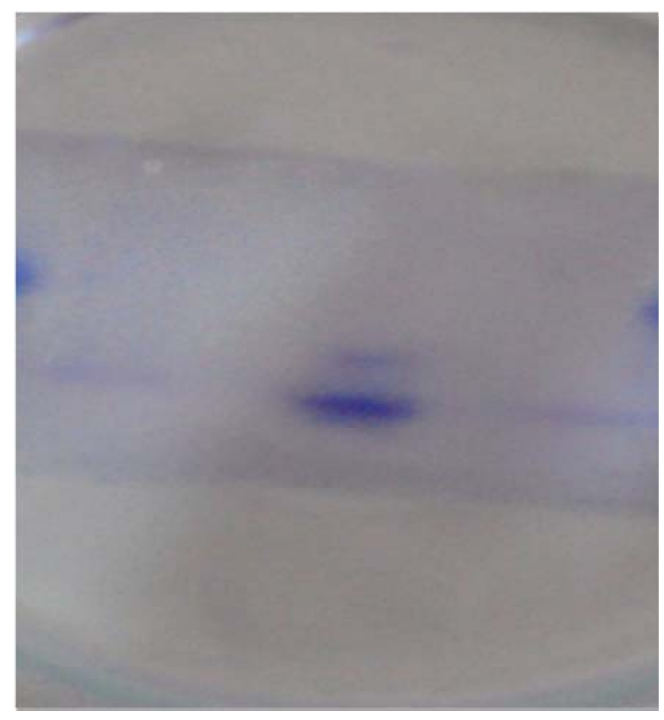

Figure 3. Polyacrylamide Gel Electrophoresis (PAGE) pattern of Indigofera heterantha lectin under native conditions. About $40 \mu \mathrm{g}$ of the purified IHL was applied on $10 \%$ polyacrylamide gel. PAGE was performed in Tris-glycine buffer, $\mathrm{pH}$ 8.0. Current applied was $25 \mathrm{~mA}$ for $2 \mathrm{hrs}$ at room temperature. 


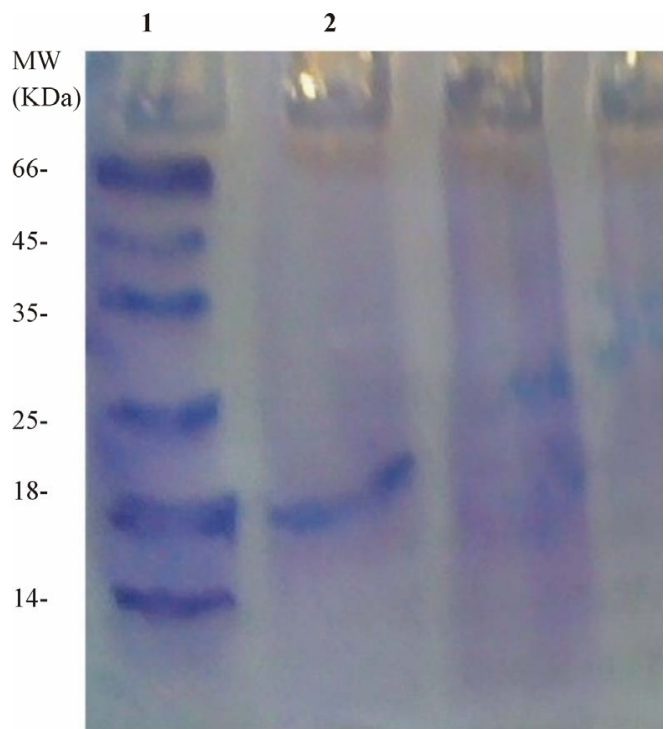

Figure 4. SDS-Polyacrylamide gel electrophoresis of Indigofera heterantha lectin. About $60 \mu \mathrm{g}$ of lectin was electrophoresed on $12 \%$ polyacrylamide gel at a current of $3.0 \mathrm{~mA} / \mathrm{well}$ in presence of $0.1 \%$ SDS. Tris-glycine buffer $\mathrm{pH} 8.0$ was used. The staining reagent used was Coomassie brilliant blue G-250. Lane 1: molecular weight markers (66 KDa, $45 \mathrm{KDa}, 35 \mathrm{KDa}, 25 \mathrm{KDa}, 18 \mathrm{KDa}$ and $14 \mathrm{KDa}$ ). Lane 2: Purified Indigofera heterantha lectin.

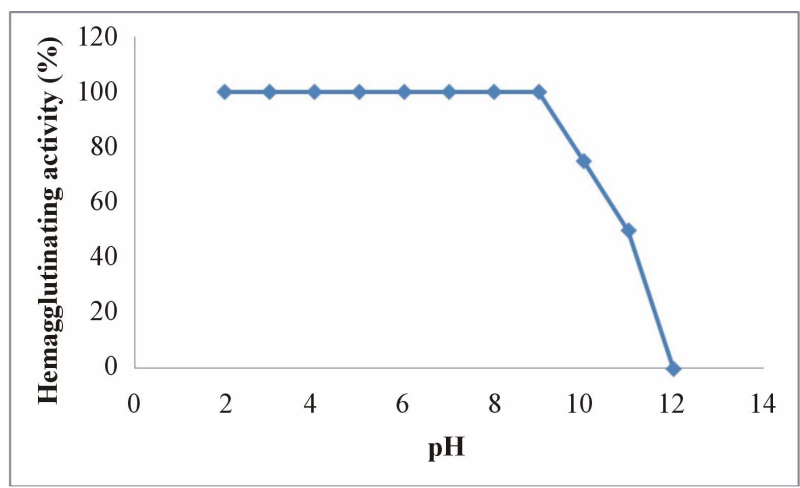

Figure 5. Effect of $\mathrm{pH}$ variations on IHL activity. The $\mathrm{pH}$ dependence of the lectin was determined by incubating $50 \mu \mathrm{g}$ of IHL with buffers in different $\mathrm{pH}: 0.1 \mathrm{M}$ glycine $/ \mathrm{HCl}(\mathrm{pH} 2-3)$, 0.05 sodium acetate/aceticacid $(\mathrm{pH} 4-5), 0.05 \mathrm{M}$ potassium phosphate (pH 6 - 7), $0.05 \mathrm{M}$ Tris- $\mathrm{HCl}(\mathrm{pH} 8$ - 9) and $0.1 \mathrm{M}$ glycine- $\mathrm{NaOH}(\mathrm{pH} 10-11)$ for $5 \mathrm{hrs}$ at $25^{\circ} \mathrm{C}$ and $\mathrm{pH}$ was adjusted to 7.2 just prior to hemagglutination assay.

protein family consists of two or four subunits (protomers), either identical or slightly different each with a single small carbohydrate combining site with the same specificity. A lectin was isolated from seeds of Indigofera heterantha using a combination of ion exchange and gel filtration chromatographies. The lectin is a tetramer and exhibits a molecular weight of $70 \mathrm{KDa}$ with a subunit $\mathrm{Mr}$ of $18 \mathrm{KDa}$. The tetrameric nature of IHL is similar to the lectin obtained from Phaseolus acutifolius

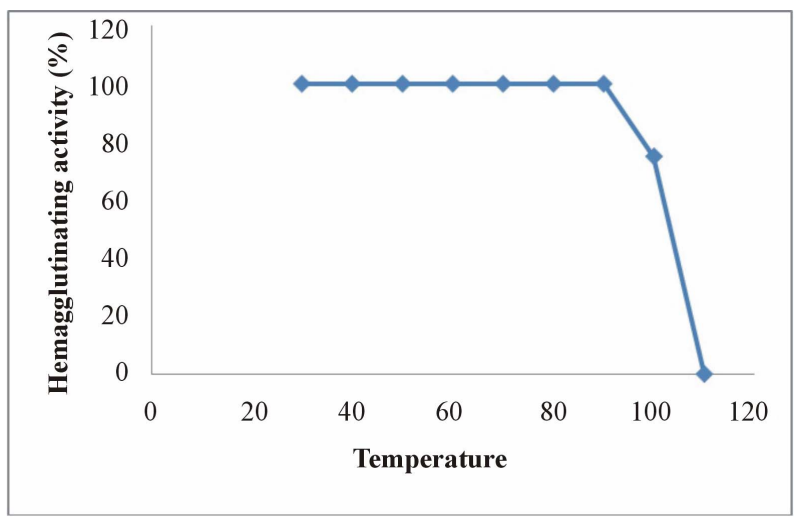

Figure 6. Effect of temperature on IHL activity. The temperature dependence of the lectin was determined by incubating the agglutination mixture $(50 \mu \mathrm{g}$ of IHL in Tris- $\mathrm{HCl}$ buffer, $\mathrm{pH} 8)$ at different temperatures for 30 , cooled to $20^{\circ} \mathrm{C}$ and determining the hemagglutination activity.

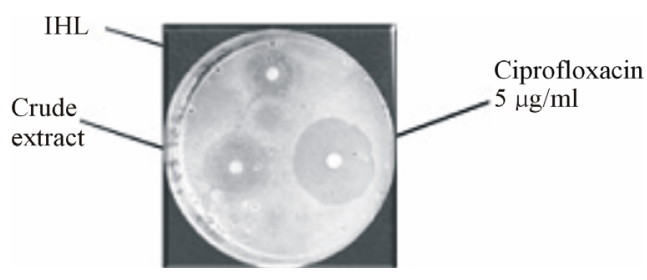

(a)

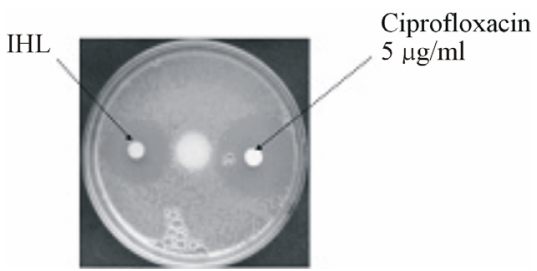

(b)

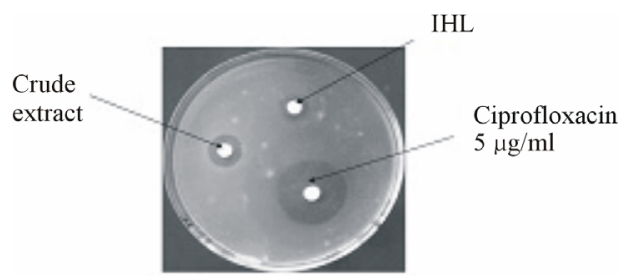

(c)

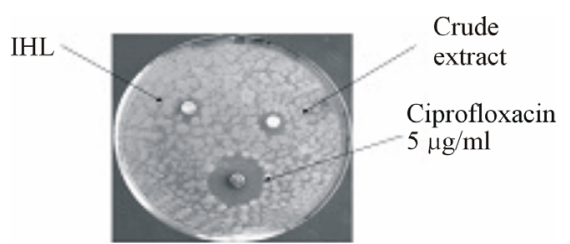

(d)

Figure 7. Antibacterial assay of Indigofera heterantha lectin with four different bacterial strains (a) Klebsiella pnuemoniae; (b) Staphylococcus aureus; (c) Escherichia coli; and (d) Bacillus subtilis. The agar disc diffusion method was used to determine antibacterial activity. Ciprofloxacin $(5 \mu \mathrm{g} / \mathrm{ml})$ was used as standard. 
Table 4. Antifungal activity of Indigofera heterantha lectin.

\begin{tabular}{|c|c|c|c|c|}
\hline \multirow[t]{2}{*}{ S.No } & \multirow[t]{2}{*}{ Organism } & \multicolumn{3}{|c|}{ Diameter of zone of inhibition (mm) } \\
\hline & & $\begin{array}{c}\text { Crude } \\
(500 \mu \mathrm{g} / \mathrm{ml})\end{array}$ & $\begin{array}{l}\text { Purified IHL } \\
(500 \mu \mathrm{g} / \mathrm{ml})\end{array}$ & $\begin{array}{c}\text { Ciprofloxacin } \\
(5 \mu \mathrm{g} / \mathrm{ml})\end{array}$ \\
\hline 1 & $\begin{array}{l}\text { Aspergillis } \\
\text { niger }\end{array}$ & 5 & 3 & 27 \\
\hline 2 & $\begin{array}{c}\text { Aspergillis } \\
\text { Oryzie }\end{array}$ & 12 & 9 & 32 \\
\hline 3 & $\begin{array}{l}\text { Fusarium } \\
\text { oxysporum }\end{array}$ & 10 & 6 & 27 \\
\hline
\end{tabular}

${ }^{*}$ Ciprofloxacin was used as a standard.

var. escumite [21]. IHL showed no specificity in its ability to hemagglutinate human ( $\mathrm{A}, \mathrm{B}, \mathrm{AB}$, and $\mathrm{O})$ erythrocytes as the lectin from Egyptian Pisum sativum seeds and Erythrina variegata lectin [22]. The hemagglutination assays showed that the lectin activity was inhibited by sucrose, D-galactose and arabinose. The carbohydrate specificity was similar to the lectin from Capsicum annum [23]. Thermal denaturation results of IHL showed that the lectin is stable up to $90^{\circ} \mathrm{C}$. Only $25 \%$ hemagglutinating activity was lost when heated at $100^{\circ} \mathrm{C}$ for 30 minutes and was completely lost at $110^{\circ} \mathrm{C}$. The heat stable nature of IHL is similar to the protein reported by Ngai et al. [24] and the lectin from Eugenia uniflora seeds [9]. The loss of hemagglutinating activity with increasing temperature is evidently due to heat induced denaturation of the lectin. This denaturation may expectedly weaken the interaction between lectin and the carbohydrate ligand leading consequently to attenuated agglutinating activity. The studied lectin showed a remarkable antibacterial activity against Bacillus subtilis, Staphylococcus aureus, Escherichia coli and Klebsiella pneumonea, Although the mechanism of action of the peptides has not yet been elucidated in detail, the presented data confirm the in vitro antibacterial activity of IHL against pathogenic bacteria. It has been proposed that the proteins with antibacterial action form a channel on cell membrane and the cell dies as a result of the out flowing of cellular contents, this mechanism being different from that of antibiotics [25]. The observed antifungal activity of IHL against Aspergillis niger, Aspergillis Oryzie and Fusarium oxysporum agrees with the results obtained from other plant legume lectins [26-28]. Antifungal activity has been related to the lectin carbohydrate binding property, that might endow lectin molecules with binding activity towards certain carbohydrate components in the fungal cell wall affecting its activity and viability as most lectins recognize either $\mathrm{N}$-acetylneuraminic acid, $\mathrm{N}$-acetylglucosamine, $\mathrm{N}$-acetyl-galactosamine, galactose, mannose, or fucose in accordance with the conclusion of Lis and Sharon [29]. These results point out that future finding of lectin applications from plants can be of great importance for clinical microbial- ogy and possible therapeutic applications.

\section{CONCLUSION}

Indigofera heterantha is an indigenous plant of the Himalayan region, but before this study no bioactive component has been isolated from it. IHL represents the first isolated proteinaceous constituent of the plant and being active against several pathogenic microorganisms could be used as an antimicrobial agent for animal and plant infections.

\section{ACKNOWLEDGEMENTS}

The authors express gratitude to UGC, India and to the Department of Biochemistry, University of Kashmir, Srinagar for providing financial assistance and other necessary support.

\section{REFERENCES}

[1] Goldstein. I.J.R.C.H., Monsigny, T. and Sharon, N. (1980) What should be called a lectin? Nature, 285, 66-72. http://dx.doi.org/10.1038/285066b0

[2] Goldstein, I.Ja.P. and Orlando, R.D. (1986) The lectins: Properties, functions and applications in biology and medicine. Academic Press, 33-247.

[3] Sharon, N. (1993) Lectin-carbohydrate complexes of plants and animals: An atomic view. Trends in Biochemical Sciences, 18, 221-226. http://dx.doi.org/10.1016/0968-0004(93)90193-Q

[4] Sharon, N. and Lis, H. (1995) Lectins-Proteins with a sweet tooth: Functions in cell recognition. Essays in Biochemistry, 30, 59-75.

[5] Etzler, M.E. (1985) Plant lectins: Molecular and biological aspects. Annual Review of Plant Physiology, 36, 209234. http://dx.doi.org/10.1146/annurev.pp.36.060185.001233

[6] Van Damme, E.J.M., Smeets, K. and Peumans, W.J. (1995) The mannose binding monocot lectins and their genes. In: Lectins: Biomedical Perspectives, Taylor and Francis Ltd., London.

[7] Battelli, M.G., Barbieri, L., Bolognesi, A., Buonamici, L., Valbonesi, P., Polito, L., et al. (1997) Ribosome-inactivating lectins with polynucleotide:adenosine glycosidase activity. FEBS Letters, 408, 355-359. http://dx.doi.org/10.1016/S0014-5793(97)00463-8

[8] Liu, B., Li, C.Y., Bian, H.J., Min, M.W., Chen, L.F. and Bao, J.K. (2009) Antiproliferative activity and apoptosisinducing mechanism of concanavalin A on human melanoma A375 cells. Archives of Biochemistry and Biophysics, 482, 1-6. http://dx.doi.org/10.1016/j.abb.2008.12.003

[9] Oliveira, M.D., Andrade, C.A., Santos-Magalhaes, N.S., Coelho, L.C., Teixeira, J.A., Carneiro-da-Cunha, M.G., et al. (2008) Purification of a lectin from Eugenia uniflora L. seeds and its potential antibacterial activity. Letters in Applied Microbiology, 46, 371-376. http://dx.doi.org/10.1111/j.1472-765X.2007.02319.x 
[10] Sun, J., Wang, L., Wang, B., Guo, Z., Liu, M., Jiang, K., et al. (2008) Purification and characterization of a natural lectin from the plasma of the shrimp Fenneropenaeus chinensis. Fish and Shellfish Immunology, 25, 290-297. http://dx.doi.org/10.1016/j.fsi.2008.06.001

[11] Bourne, Y., Ayouba, A., Rouge, P. and Cambillau, C. (1994) Interaction of a legume lectin with two components of the bacterial cell wall. A crystallographic study. The Journal of Biological Chemistry, 269, 9429-9435.

[12] Lis, H. and Sharon, N. (1981) Lectins in higher plants. In: Marcus, A., Ed., The Biochemistry of Plants, Academic Press, New York, 371-447.

[13] Lowry, O.H., Rosebrough, N.J., Farr, A.L. and Randall, R.J. (1951) Protein measurement with the Folin phenol reagent. The Journal of Biological Chemistry, 193, 265275.

[14] Cammue, B.P., Peeters, B. and Peumans, W.J. (1985) Isolation and partial characterization of an N-acetylgalactosamine-specific lectin from winter-aconite (Eranthis hyemalis) root tubers. The Biochemical Journal, 227, 949955.

[15] Ngai, P.H. and Ng, T.B. (2007) A mannose-specific tetrameric lectin with mitogenic and antibacterial activities from the ovary of a teleost, the cobia (Rachycentron canadum). Applied Microbiology and Biotechnology, 74, 433-438. http://dx.doi.org/10.1007/s00253-006-0649-2

[16] Wang, H., Ye, X.Y. and Ng, T.B. (2001) Purification of chrysancorin, a novel antifungal protein with mitogenic activity from garland chrysanthemum seeds. Biological Chemistry, 382, 947-951. http://dx.doi.org/10.1515/BC.2001.118

[17] Laemmli, U.K. (1970) Cleavage of structural proteins during the assembly of the head of bacteriophage T4. Nature, 227, 680-685. http://dx.doi.org/10.1038/227680a0

[18] Andrews, P. (1970) Estimation of molecular size and molecular weights of biological compounds by gel filtration. Methods of Biochemical Analysis, 18, 1-53. http://dx.doi.org/10.1002/9780470110362.ch1

[19] Edward, A. (2001) Microbiology. Jones and Bartlett Publishers, Massacheustte.

[20] Lansing, M., Prescott, J.P.H. and Donald, A.K. (2006) Microbiology. 6th Edition, McGraw Hill, New York.
[21] Castillo-Villanueva, A., Caballero-Ortega, H., AbdullaevJafarova, F., Garfias, Y., del Carmen Jimenez-Martinez, M., Bouquelet, S., et al. (2007) Lectin from Phaseolus acutifolius var. escumite: Chemical characterization, sugar specificity, and effect on human T-lymphocytes. Journal of Agricultural and Food Chemistry, 55, 5781-5787. http://dx.doi.org/10.1021/jf063644k

[22] Datta, T.K. and Basu, P.S. (1983) Human erythrocyte specific lectin from the seeds of Indian coral tree, Erythrina variegata Linn, var. orientali Linn, Merrill. Journal of Bioscience, 5, 25-30.

[23] Adenike, K.O.O., Kemi, A.M.A. and Toyin, O. (2009) Purification of a mannose/glucose-specific lectin with antifungal activity from pepper seeds (Capsicum annuum). African Journal of Biochemistry Research, 3, 272-278.

[24] Ngai, P.H. and Ng, T.B. (2004) A mushroom (Ganoderma capense) lectin with spectacular thermostability, potent mitogenic activity on splenocytes, and antiproliferative activity toward tumor cells. Biochemical and Biophysical Research Communications, 314, 988-993. http://dx.doi.org/10.1016/j.bbrc.2003.12.196

[25] Talas-Ogras, T., Ipekci, Z., Bajrovic, K. and Gozukirmizi, N. (2005) Antibacterial activity of seed proteins of Robinia pseudoacacia. Fitoterapia, 76, 67-72. http://dx.doi.org/10.1016/j.fitote.2004.10.020

[26] Yan, Q., Jiang, Z., Yang, S., Deng, W. and Han, L. (2005) A novel homodimeric lectin from Astragalus mongholicus with antifungal activity. Archives of Biochemistry and Biophysics, 442, 72-81.

http://dx.doi.org/10.1016/j.abb.2005.07.019

[27] Ciopraga, J., Gozia, O., Tudor, R., Brezuica, L. and Doyle, R.J. (1999) Fusarium sp. growth inhibition by wheat germ agglutinin. Biochimica et Biophysica Acta, 1428, 424 432. http://dx.doi.org/10.1016/S0304-4165(99)00085-9

[28] Ye, X.Y., Ng, T.B., Tsang, P.W. and Wang, J. (2001) Isolation of a homodimeric lectin with antifungal and antiviral activities from red kidney bean (Phaseolus vulgaris) seeds. Journal of Protein Chemistry, 20, 367-375. http://dx.doi.org/10.1023/A:1012276619686

[29] Lis, H. and Sharon, N. (1998) Lectins: Carbohydrate-Specific proteins that mediate cellular recognition. Chemical Reviews, 98, 637-674.

http://dx.doi.org/10.1021/cr940413g 